Die quantitative Bestimmung von Proteinen durch radiale Immundiffusion stellt ein einfaches, empfindliches, ausreichend genaues und gut reproduzierbares Verfahren zur spezifischen Quantifizierung einzelner Proteine in Körperflüssigkeiten dar. Diese Methode bedeutet gegenüber der papierelektrophoretischen Gruppenanalyse von Proteingemischen eine wesent- liche Bereicherung unserer diagnostischen Möglichkeiten.

Herrn OMR Priv.-Doz. Dr. BuBE, Leiter der Blutspendezentrale der Chirurg. Univ. Klinik Köln, danken wir für die Uberlassung von Blutspenderseren.

Der Deutschen Forschungsgemeinschaft danken wir für Sachbeihilfen.

\title{
Literatur
}

1. Wuhrmann, F. und H. Märki, Dysproteinämien und Paraproteinämien. Schwabe u. Co, Basel, Stuttgart (1963). - 2. WaAler, E., Acta med. Scand. 17, 172 (1940). - 3. Miescher, P. und M. Fauconnet, Experientia (Basel), 10, 252 (1954). - 4. Anderson, J. R., W. W. Buchanan, R. B. Gondie und K. G. Gray, J. Clin. Path. (London) 15, 462 (1962). - 5. Schumacher, K., W. Schneider und R. Gross, Àrztl. Lab. 13, 45 (1967). 6. Heidelberger, M. und F. E. Kendall, J. Exper. Med. 55, 555 (1931). - 7. Goodman, M., D. S. Ramsey, W. L. Simpson, D. G. Remp, D. H. Basinski und M. J. Brennan, J. Laborat. Clin. Med. S. Louis, 49, 151 (1957). - 8. HoignÉ, R., E. Huber-Stoller, G. Golex, F. Rodriguez und H. Isliker, Schweiz. med. Wschr. 88, 331 (1958). - 9. Schultze, H. E. und G. Schwick, Clin. chim. Acta (Amsterdam) 4, 15 (1959). - 10. Oudrn, J., in A. C. Corcoran, Methods in medical research. Vol. 5, S. 56 Year Book Publ. Chicago (1952). - 11. FernBerg, J. G., Internat. Arch. Allergy, 11, 129 (1957). - 12. HaYward, B. J. und R. Augustin, Internat. Arch. Allergy 11, 192 (1957). - 13. Mancini, G., J. P. Vaerman, A. O. Carbonara und J. F. Heremans, in H. Peeters: Proteins of the biological fluids. Elsevier Publ. Amsterdam (1964). 14. Ouchterlony, O., Acta path. mïrobiol. Scand. 32, 231
(1953). - 15. Hrtzig, W. H., Internat. Arch. Allergy 19, 145 (1961). - 16. Goetrsch, E. und F. E. Kendall, J. biol. Chemistry 109, 221 (1935). - 17. Markowitz, H., C. J. Gubler, J. P. Mahoney, G. E. Cartwright und M. M. Wintrobe, J. clin. Invest. 34, 1498 (1955). - 18. Frohman, C. E., M. Goodman, E. D. Luby, P. G. S. Beckett und R. Senf, Arch. Neurol. Psychiatr. (Chicago) 79, 730 (1958). - 19. Roth, N., Ann. paediatr. Basel, 199, 548 (1962). - 20. WERDER-KIND, H., Helvet. paediatr. Acta 18, 450 (1963). - 21. Huntrey, C. C., Pediatrics (Springfield) 31, 123 (1963). - 22. Fahey, J. L. und M. E. LAwrence, J. Immunol. (Baltimore) 91, 597 (1963). - 23. Werss, W. A., Klin. Wschr. 43, 273 (1965). - 24. McKeLVEY, E. M. und J. L. FAhey, J. clin. Invest. 44, 1778 (1965). - 25. Stiehm, E. R. und H. H. Fudenberg, Pediatrics (Springfield) 37, 715 (1966). 26. Haferkamp, O., D. Schlettwein-Gsell, H. G. Schwick und K. Störiko, Getontologia 12, 30 (1966). - 27. Ravin, R. A., Lancet (London) I 726 (1956). - 28. Vella, F., Med. J. Malaya 12, 456 (1957). - 29. Sass-Kortsack, A., M. Cherniak, D. W. Geiger und R. J. Slater, J. clin. Invest. 38, 1672 (1959). 30. Cohen, S. und R. R. Porter, Biochem. J. 90, 278 (1964).

\section{Haemoglobin Oxygen Saturation as determined by Interference Filter Photometry: Sources of Error ${ }^{1}$ )}

\author{
By P. LundsgaArd-Hansen and U. Schreiber \\ From the Department of Surgical Research, University Department of Surgery, Inselspital, Berne, Switzerland
}

(Eingegangen am 13. Januar 1968)

For the measurement of haemoglobin oxygen saturation by interference filter photometry, two sources of error must be allowed for: first, the apparatus constants $\left(\mathrm{D}_{\mathrm{R}} / \mathrm{D}_{\mathrm{G}}\right)_{\mathrm{HbO}_{2}}$ and $\left(\mathrm{D}_{\mathrm{R}} / \mathrm{D}_{\mathrm{G}}\right)_{\mathrm{Hb}}$ differ for blood from various species. Second, the ratio $\mathrm{D}_{\mathrm{G}}\left(\mathrm{Hb} \mathrm{O}_{2} / \mathrm{Hb}\right)$ may deviate significantly from 1.0; i. e. the green filter may not be isosbestic. The accuracy of the method was assessed and the effects of both sources of error calculated. The agreement with the van Slyke method is good when these errors are eliminated. In the following paper, a nomogram is presented which can be adapted to the differences between species and filters.

Bei der Messung der Sauerstoffșättigung des Hämoglobins mittels Interferenzfilterphotometrie sind zwei Fehlerquellen zu berücksichtigen: Erstens sind die Apparatekonstanten $\left(D_{R} / D_{G}\right)_{H_{b O}}$ und $\left(D_{R} / D_{G}\right)_{\text {Hb }}$ von Spezies zu Spezies verschieden. Zweitens kann das Verhältnis $\mathrm{D}_{\mathrm{G}}\left(\mathrm{HbO}_{2} / \mathrm{Hb}\right)$ von 1,0 signifikant differieren, $\mathrm{d}$. h. das grüne Interferenzfilter nicht isosbestisch sein. Die Genauigkeit der Methode wurde geprüft und die Auswirkungen der Fehlerquellen berechnet. Werden sie eliminiert, so ergibt sich eine gute Ubereinstimmung mit der van Slyke-Methode. In der folgeriden Arbeit wird ein Nomogramm vorgelegt, das den Variationen zwischen Spezies und Filtern angepaßt werden kann.

In clinical and laboratory work, the oxygen saturation of the blood frequently yields essential information. Its determination by manometric methods, although unsurpassed as to accuracy, consumes so much time that difficulties often arise with large sample numbers. For this reason, the more rapid photoelectric methods are widely used.

1) Work supported by Research Grant No. 4139 from the Swiss National Foundation for the Advancement of Scientific Research.
Reflection oximetry as inaugurated by ZiJLSTRA (1) has gained widespread acceptance. With this method, oxygen saturation in the higher range can be rapidly and accurately determined. According to ZijLstra and VAN Mook, however; it suffers from the disadvantage that it yields falsely high values for oxygen saturations less than 30 per cent (2). In our laboratory (3), and as also reported by COLE and HAwrins (4), this systematic error is already present at higher saturation 
values, i. e. below 45 per cent. Similar difficulties are encountered with other oxymetric methods (4). By contrast, the spectrophotometric methods originated by Drabkin (5) and developed further by NaHAS (6) and SiggaARD-ANDERSEN (7) are essentially reliable over the whole saturation range (cf. (4)).

As originally described, these methods require an extremely accurate control of the wavelength setting (7). Recently, SiggaARD-ANDERSEN has constructed an oxygen saturation meter ${ }^{1}$ ) which eliminates this source of error by the use of two interference filters with maximum transmissions at approximately 505 and $600 \mathrm{~nm}$. A nomogram for the calculation of the oxygen saturation of normal human blood is supplied with this instrument, which works rapidly, accurately and with small samples $(50 \mu l)$ for a single determination.

This procedure offers considerable advantages for the analysis of multiple samples especially from small animals in which sample size may be critical. In a recent study of five commercially available oximeters (4), Cole and Hawnins found it to yield the most satisfactory agreement with the VAN SLYKe method. As other workers will undoubtedly also be interested in the method, we want to report two sources of error which we have encountered. First, there are slight, but significant differences between haemoglobins from various species when their oxygen saturations are determined with this instrument. Second, the green interference filter with a maximum transmission at $505 \mathrm{~nm}$ may not be strictly isosbestic. Erroneous results may therefore be obtained when the standard calculation procedure or the standard nomogram are used.

In this paper, we report our results with oxygen saturation measurements on human, dog and rabbit blood with the oxygen saturation meter developed by SiggaARD-ANDERSEN. In the following paper (8), EHRENGRUBER presents a calculation procedure and a nomogram which can be applied to oxygen saturation measurements with a two-wavelength method based on interference filter photometry. This nomogram can be adapted to different haemoglobins and also to deviations of the green filter transmission from the isosbestic point at $505 \mathrm{~nm}$.

\section{Material and methods}

1. The apparatus constants $\left(D_{R} / D_{G}\right)_{H_{b O}},\left(D_{R} / D_{G}\right)_{H b}$ and $\mathrm{D}_{\mathrm{G}}\left(\mathrm{HbO}_{2} / \mathrm{Hb}\right)$ were determined on blood samples obtained from each of 5 healthy non-smokers and from 10 normal dogs and rabbits. The dogs were unsedated or had been anaesthetized with Nembutal ( $30 \mathrm{mg} / \mathrm{kg}$ body weight) at the beginning of experiments performed for other purposes. The rabbits had been sedated with Nembutal $(15 \mathrm{mg} / \mathrm{kg})$ and a plastic catheter introduced into the femoral artery or vein under local procaine infiltration. All animal blood samples utilized for the determination of the constants mentioned were drawn under control conditions, i. e. before any further experimental variables were introduced.

Full saturation and full desaturation of the samples were obtained by the procedure specified in the instruction manual supplied with the instrument: To obtain full saturation, the blood sample was equilibrated for $5 \mathrm{~min}$. with a mixture of some $5 \% \mathrm{CO}_{2}$ and some

1) Oxygen Saturation Meter OSM 1, Radiometer, Copenhagen.
95\% $\mathrm{O}_{2}$ in the equilibration chamber of the Astrup microequipment $\mathrm{AME} 1^{2}$ ) for the measurement of $\mathrm{pH}, \mathrm{pCO}_{2}$ and standard bicarbonate. Full desaturation was produced by mixing equal volumes of blood and the reducing solution recommended by the manufacturers in capillary tubes of $75 \mathrm{~mm}$ length. This solution contains $120 \mathrm{mg}$ of sodium dithionite and $95 \mathrm{mg}$ borax in $10 \mathrm{ml}$ water which has been boiled for some minutes and cooled again shortly before use. The capillaries with the blood samples were centrifuged at 15.000 r. p. m. and haemolyzed in the haemolyzer HEM $1^{2}$ ). In this way, an extinction value between 0.8 and 1.1 scale units at $505 \mathrm{~nm}$ was obtained, as recommended by the manufacturer. In every other detail, the procedure specified in the instruction manual supplied with the instrument was followed exactly.

2. The methodical error was assessed by measurements of the actual oxygen saturation of blood samples in the 90,50 and 10 per cent saturation range. For the high saturation range, such measurements were performed on human, dog and rabbit blood. For the medium and low saturation range, they were done on animal blood only, which was obtained during the further course of experiments. All calculations except those done to assess the errors introduced by following the standard procedure were performed with the formulas given by EHRENGRUBER in the following paper (8).

3. The validity of the measurements and the calculation procedure was checked by comparing the results obtained by interference filter photometry of several arterial blood samples with control determinations on the same samples by the VAN SLYKE method. The results obtained by manometric measurement were calculated with the standard procedure for human blood ${ }^{3}$ ).

4. The accuracy attained when determining the constants and in the measurement of actual oxygen saturations were evaluated by the usual statistical parameters: Standard deviation SD, standard error of the mean SEM, $95 \%$ confidence interval defined as $\bar{x}=1.96 \cdot S E M$, and the coefficient of variation, defined as $\underline{\mathrm{SD} \cdot 100}$

$\overline{\mathbf{x}}$

\section{Results}

\section{Apparatus constants}

The values for $\left(D_{R} / D_{G}\right)_{\text {Hbо }},\left(D_{R} / D_{G}\right)_{\text {Hb }}$ and $D_{G}$ $\left(\mathrm{HbO}_{2} / \mathrm{Hb}\right)$ established for our instrument are summarized in Table 1.

First, it is seen that the constants $\left(D_{R} / D_{G}\right)_{H_{b o}}$ and $\left(D_{R} / D_{G}\right)_{\text {H }}$ differ for blood from the species examined. As judged by the $95 \%$ confidence intervals given in Table 1, the differences are significant at the 5 per cent level.

Second, the green filter with maximum transmission at approximately $505 \mathrm{~nm}$ was found not to be isosbestic. The ratio $\mathrm{D}_{\mathrm{G}}\left(\mathrm{HbO}_{2} / \mathrm{Hb}\right)$ differs from 1.0 for all species at the 5 per cent level. This being so, the standard calculation procedure underlying the nomogram constructed by SIGGAARD-ANDERSEN should not be applied.

It should be understood that the constants given in Table 1 are strictly valid only for the instrument on which they were determined. The differences in the filters supplied with different instruments make it necessary to establish these constants for each instrument

2) Radiometer, Copenhagen.

3) We are indebted to Prof. M. Scherrer, Head of the Pulmonary Function Laboratory, University Department of Medicine, for his generous aid with these analyses. 
Tab. 1

Apparatus constants for human, dog and rabbit blood

\begin{tabular}{|c|c|c|c|c|c|c|c|}
\hline & Factor & $\overline{\bar{x}}$ & $\mathbf{N}$ & SD & SEM & $\begin{array}{l}95 \% \text { confidence } \\
\text { interval }\end{array}$ & $\begin{array}{c}\text { coefficient of } \\
\text { variation }\end{array}$ \\
\hline Man & $\begin{array}{c}\left(D_{R} / D_{G}\right)_{\mathrm{HbO}_{2}} \\
\left(D_{R} / D_{G}\right)_{\mathrm{Hb}} \\
D_{G}\left(\mathrm{HbO}_{2} / \mathrm{Hb}\right)\end{array}$ & $\begin{array}{l}0.129 \\
0.567 \\
1.08\end{array}$ & $\begin{array}{l}50 \\
50 \\
50\end{array}$ & $\begin{array}{l}0.0045 \\
0.0220 \\
0.0340\end{array}$ & $\begin{array}{l}0.0006 \\
0.0031 \\
0.0048\end{array}$ & $\begin{array}{c}0.128-0.130 \\
0.561-0.573 \\
1.07-1.09\end{array}$ & $\begin{array}{l}3.49 \\
3.88 \\
3.15\end{array}$ \\
\hline Dog & $\begin{array}{c}\left(D_{R} / D_{G}\right)_{H_{b O}} \\
\left(D_{R} / D_{G}\right)_{H b} \\
D_{G}\left(\mathrm{HbO}_{2} / \mathrm{Hb}\right)\end{array}$ & $\begin{array}{l}0.125 \\
0.550 \\
1.11\end{array}$ & $\begin{array}{l}58 \\
56 \\
56\end{array}$ & $\begin{array}{l}0.0054 \\
0.0266 \\
0.0624\end{array}$ & $\begin{array}{l}0.0007 \\
0.0035 \\
0.0083\end{array}$ & $\begin{array}{c}0.124-0.126 \\
0.543-0.557 \\
1.09-1.13\end{array}$ & $\begin{array}{l}4.32 \\
4.84 \\
5.62\end{array}$ \\
\hline Rabbit & $\begin{array}{l}\left(D_{R} / D_{G}\right)_{H b o_{3}} \\
\left(D_{R / D} / D_{G}\right)_{H b} \\
D_{G}\left(\mathrm{Hbo}_{2} / \mathbf{H b}\right)\end{array}$ & $\begin{array}{l}0.120 \\
0.519 \\
1.08\end{array}$ & $\begin{array}{l}\mathbf{5 0} \\
\mathbf{5 0} \\
\mathbf{5 0}\end{array}$ & $\begin{array}{l}0.0047 \\
0.0265 \\
0.1060\end{array}$ & $\begin{array}{l}0.0007 \\
0.0037 \\
0.0150\end{array}$ & $\begin{array}{c}0.119-0.121 \\
0.512-0.526 \\
1.05-1.11\end{array}$ & $\begin{array}{l}3.92 \\
5.12 \\
9.81\end{array}$ \\
\hline
\end{tabular}

Tab. 2

Method errors in the high, medium and low saturation range

\begin{tabular}{|c|c|c|c|c|c|c|c|}
\hline & $\begin{array}{c}\text { Saturation } \\
\text { range }\end{array}$ & $\overline{\bar{x}}$ & $\mathbf{N}$ & SD & SEM & $\begin{array}{c}95 \% \text { confidence } \\
\text { interval }\end{array}$ & $\begin{array}{c}\text { coefficient of } \\
\text { variation }\end{array}$ \\
\hline Man & high & 85.0 & 10 & 0.537 & 0.170 & $84.67-85.33$ & 0.63 \\
\hline Dog & $\begin{array}{l}\text { high } \\
\text { medium } \\
\text { low }\end{array}$ & $\begin{array}{r}93.9 \\
52.0 \\
9.9\end{array}$ & $\begin{array}{l}10 \\
10 \\
10\end{array}$ & $\begin{array}{l}0.903 \\
1.532 \\
0.979\end{array}$ & $\begin{array}{l}0.268 \\
0.485 \\
0.310\end{array}$ & $\begin{array}{r}93.36-94.41 \\
51.07-52.97 \\
9.30-10.52\end{array}$ & $\begin{array}{l}0.96 \\
2.95 \\
9.88\end{array}$ \\
\hline Rabbit & $\begin{array}{c}\text { high } \\
\text { medium } \\
\text { low }\end{array}$ & $\begin{array}{l}96.9 \\
41.8 \\
11.3\end{array}$ & $\begin{array}{l}10 \\
10 \\
10\end{array}$ & $\begin{array}{l}0.695 \\
1.277 \\
0.760\end{array}$ & $\begin{array}{l}0.220 \\
0.404 \\
0.269\end{array}$ & $\begin{array}{l}96.47-97.33 \\
41.01-42.59 \\
10.77-11.83\end{array}$ & $\begin{array}{l}0.72 \\
3.06 \\
6.73\end{array}$ \\
\hline
\end{tabular}

separately. The values given in Table 1 may serve as reference for other workers interested in such measurements.

\section{Methodical error}

The methodical errors established by 10 measurements each on blood samples with saturations in the high, medium and low range are summarized in Table 2.

As expected, the magnitude of the relative error reflected by the coefficient of variation increases as the average absolute value decreases. However, the accuracy of the method also appears to be satisfactory in the low saturation range. In a study of oxygen saturations in coronary sinus blood in the 5 to 10 per cent range, BRETSCHNEIDER (9) stated the methodical error of the VAN SIYKE method to be 0.2 vol\%, equalling 1 per cent saturation. The error inherent in the method discussed here is no greater than this.

\section{Comparison with the van Slyke method}

In 17 arterial blood samples from human patients, dogs and rabbits, the values obtained by interference filter photometry and the calculation procedure or the nomogram developed by EHRENGRUBER (8) were, on the average, $1.5 \%$ higher than those found with the VAN SLYKE method. The standard deviation of the difference was $3.5 \%$, the standard error of the mean $0.85 \%$. If the $95 \%$ confidence interval is calculated as stated under methods, the average difference of $+1.5 \%$ is found not to differ from zero at the 5 per cent level. Cole and HAwkins (4) found an average difference between the interference filter photometer and the VAN SLYKE method of $+0.9 \%$ with a standard deviation of $0.8 \%$.

\section{Discussion}

Our results demonstrate that when the oxygen saturation of haemoglobin from different species is determined by interference filter photometry on the oxygen saturation meter developed by SIGGAARDANDERSEN, two sources of errors must be allowed for: The apparatus constants $\left(\mathrm{D}_{\mathrm{R}} / \mathrm{D}_{\mathrm{G}}\right)_{\text {н } \mathrm{O}_{2}}$ and $\left(\mathrm{D}_{\mathrm{R}} / \mathrm{D}_{\mathrm{G}}\right)_{\text {н } \mathrm{b}}$ differ significantly for haemoglobins from various species and the green filter with an approximate maximum transmission at $505 \mathrm{~nm}$ may not be isosbestic, i.e. the ratio $\mathrm{D}_{\mathrm{G}}\left(\mathrm{HbO}_{2} / \mathrm{Hb}\right)$ may deviate significantly from 1.0. The importance of considering these discrepancies is best illustrated by a brief discussion of the errors introduced if they are neglected.

By the standard formula on which the nomogram constructed by SIGGAARD-ANDERSEN is based, oxygen saturation is calculated as:

per cent oxygen saturation $=A-B\left(D_{R} / D_{G}\right) x$,

where $A$ is $=\left(D_{R} / D_{G}\right)_{\text {Hb }} \times 100 /\left(D_{R} / D_{G}\right)_{H b}-\left(D_{R} /\right.$ $\mathrm{DG}_{\mathrm{G}}{\text { Н } \mathrm{O}_{2}}$

and $B$ is $=100 /\left(D_{R} / D_{G}\right)_{\text {Hb }}-\left(D_{R} / D_{G}\right)_{\text {H }_{2}}$

This formula is based on the assumption that the ratio $\mathrm{D}_{\mathrm{G}}\left(\mathrm{HbO}_{2} / \mathrm{Hb}\right)$ is $=1.0$, i. e. that the green interference filter is strictly isosbestic.

With our instrument and for normal adult human blood, $\mathrm{A}=129.4$ and $\mathrm{B}=228.3$. For dog and rabbit blood, we find these constants to be 129.4 and 235.3 and 130.1 and 250.6 , respectively. If the oxygen saturations given in Table 2 for dog and rabbit blood are calculated with the constants established for human blood and with the standard equation, large errors are introduced. The results will be $1.8-2.7$ per cent too high in the high saturation range, $5.1-8.0$ per cent too high in the medium and 5.1-10.1 per cent too high in the low saturation range. If the saturations are calculated with the constants established for each species but with the standard equation, i. e. distegarding the fact that the green filter is not isosbestic, the positive error still amounts to $0.2-0.5 \%, 2.2-2.6 \%$ and $1.4-1.6 \%$ in the high, medium and low saturation ranges, respecti- 
vely. By itself, this error may not appear to be large, but as it may further increase the discrepancy. found between the manometric and the photometric values, we consider that it should be avoided.

As with the existing nomogram developed by SiGGAARD-ANDERSEN, the per cent oxygen saturation scale of the nomogram presented by EHRENGRUBER in the following paper (8) must be constructed for each instrument (i. e. each set of filters) and for the species which is to be investigated. Its advantage lies in its general applicability to a two-wavelength method for the determination of the per cent oxygen saturation of different haemoglobins with interference filters, one of which has a maximum transmission close to, but not necessarily identical with the isosbestic wavelength for oxyhaemoglobin and reduced haemoglobin.

\title{
References
}

1. ZijLstrA, W. G., A manual of reflection oximetry. van Gorcum \& Co., Assen (1958). - 2. ZijLstra, W. G. and G. A. vaN Mook, Medical reflection photometry. van Gorcum \& Co., Assen (1962). - 3. WAHLEN, S., Vergleichende Messungen der Sauerstoffsättigung des Blutes mittels Hämoreflektor und Spektrophotometrie. Inaug. Diss., Bern 1966. - 4. Cole, P. V. and L. H. Hawkins, Bio-medical Engineering 2, 56 (1967). - 5.
Drabkin, D. L. and J. H. Austin, J. biol. Chemistry 112, 51 (1935). - 6. NaHAS, G. G., Science Washington 113, 723 (1951). 7. SiggaArd-Andersen, O., K. Jørgensen and N. NaeraA, Scand. J. Clin. Laborat. Invest. 14, 298 (1962). - 8. EHRENGRUBER, H., diese Z. 6, 200 (1968). 9. BretschneIder, H. J., A. FranK, E. Kanzow and U. Bernard, Pflügers Arch. Physiol. 264, 399 (1957).
PD Dr. P. Lundsgaard-Hansen Inselspital $\mathrm{CH} 3008$ Bern (Switzerland)

\section{A new Nomogram for the Calculation of Haemoglobin Oxygen Saturation by Interference Filter Photometry}

\author{
By H. Ehrengruber \\ From the Central Chemical Laboratory, Inselspital, Berne (Switzerland)
}

(Eingegangen am 13. Januar 1968)

\begin{abstract}
As shown. in the preceding paper, the standard procedure for the calculation of haemoglobin oxygen saturation by a two-wavelength method and the existing nomogram are not generally valid when interference filters are employed. A calculation procedure and a nomogram are presented which are generally valid and which can be adapted to the differences between interference filters and haemoglobins from different species.

Wie in der vorangehenden Arbeit gezeigt wurde, ist das Standardverfahren zur Berechnung der Sauerstoffsättigung des Hämoglobins nicht allgemein gültig, wenn bei zwei Wellenlängen mit Interferenzfiltern gearbeitet wird. Das gleiche gilt für das bisher vorliegende Nomogramm. Es wird ein allgemein gültiges Berechnungsverfahren und ein Nomogramm vorgelegt, die den unterschiedlichen Eigenschaften der Interferenzfilter uṇd der Hämoglobine verschiedener Spezies angepaßt werden können.
\end{abstract}

The standard formulas applicable to the determination of haemoglobin oxygen saturation by a two-wavelength spectrophotometric method are:

$$
\mathrm{O}_{2} \%=\frac{\left[\left(D_{R} / D_{G}\right)_{H b}-\left(D_{R} / D_{G}\right)_{x}\right] \cdot 100}{\left(D_{R} / D_{G}\right)_{H b}-\left(D_{R} / D_{G}\right)_{H b O}}
$$

or:

where:

$$
\mathrm{O}_{2} \%=\mathrm{A}-\mathrm{B} \cdot\left(\mathrm{D}_{\mathrm{R}} / \mathrm{D}_{\mathrm{G}}\right)_{\mathbf{x}}
$$

$$
A=\frac{\left(D_{R} / D_{G}\right)_{H b} \cdot 100}{\left(D_{R} / D_{G}\right)_{H b}-\left(D_{R} / D_{G}\right)_{H b O_{2}}}
$$

and

$$
\mathrm{B}=\frac{100}{\left(\mathrm{D}_{\mathrm{R}} / \mathrm{D}_{\mathrm{G}}\right)_{\mathrm{Hb}}-\left(\mathrm{D}_{\mathrm{R}} / \mathrm{D}_{\mathrm{G}}\right)_{\mathrm{HbO}}} .
$$

These formulas are valid only if the green wavelength $(505 \mathrm{~nm})$ equals the isosbestic point for reduced haemoglobin and oxyhaemoglobin, $\dot{i}$. e. if the ratio $D_{G}$, Hbo $_{2} /$ $D_{G}$, пь is 1.0. If this premise is not valid, as may. be the case when interference filters are employed (1), the following formula has to be used for the calculation of the per cent oxygen saturation:

$$
\begin{array}{r}
\mathrm{O}_{2} \% \frac{\left[\left(\frac{D_{R}}{D_{G}}\right)_{\text {Hb }}-\left(\frac{D_{R}}{D_{G}}\right)_{X}\right] \cdot 100}{\left(\frac{D_{R}}{D_{G}}\right)_{\text {Hb }}-\left(\frac{D_{R}}{D_{G}}\right)_{\mathrm{HbO}_{2}}+\left[\left(\frac{D_{R}}{D_{G}}\right)_{\mathrm{HbO}_{2}}-\left(\frac{D_{R}}{D_{G}}\right)_{X}\right]} \\
\cdot\left[1-\frac{D_{G}, \text { HbO }_{2}}{D_{G}, \text { Hb }}\right]
\end{array}
$$

For human blood, the following constants were found (1):

$$
\begin{aligned}
& \left(D_{R} / D_{G}\right)_{H b}=0.567 ;\left(D_{R} / D_{G}\right)_{H b O_{2}}=0.129 ; \\
& \mathrm{D}_{G, \text { HВO }_{2}} / \mathrm{D}_{\mathrm{G}, \text { 耳b }}=1.08 \text {. }
\end{aligned}
$$

Since the calculation of oxygen saturation by equation [2] is very cumbersome, a simpler computing formula is desirable. By inserting the constants given above in equation [2], we obtain (after transforming the denominator):

$$
\mathrm{O}_{2} \%=\frac{0.567-\left(D_{R} / D_{G}\right)_{x}}{0.428-0.08\left(D_{R} / D_{G}\right)_{x}} \cdot 100
$$

